\title{
Livin expression is an independent factor in rectal cancer patients with or without preoperative radiotherapy
}

\author{
Zhen-Yu Ding ${ }^{1,2}$, Hong Zhang ${ }^{3}$, Gunnar Adell ${ }^{4}$, Birgit Olsson ${ }^{1}$ and Xiao-Feng Sun ${ }^{*}$
}

\begin{abstract}
Background: This study was aimed to investigate the expression significance of Livin in relation to radiotherapy (RT), clinicopathological and biological factors of rectal cancer patients.

Methods: This study included 144 primary rectal cancer patients who participated in a Swedish clinical trial of preoperative radiotherapy. Tissue microarray samples from the excised primary rectal cancers, normal mucosa and lymph node metastases were immunostained with Livin antibody. The proliferation of colon cancer cell lines SW620 and RKO was assayed after Livin knock-down.

Results: The expression of Livin was significantly increased from adjacent $(P=0.051)$ or distant $(P=0.028)$ normal mucosa to primary tumors. 15.4\% (2/13) and 39.7\% (52/131) patients with Livin-negative and positive tumors died at 180 months after surgery, and the difference tended to be statistically significant $(P=0.091)$. In multivariate analyses, the difference achieved statistical significance, independent of TNM stage, local and distant recurrence, grade of differentiation, gender, and age (odds ratio $=5.09,95 \% \mathrm{Cl}: 1.01-25.64, P=0.048$ ). The in vitro study indicated colon cancer cells with Livin knock-down exhibited decreased proliferation compared with controls after RT.
\end{abstract}

Conclusions: The expression of Livin was was independently related to survival in rectal cancer patients, suggesting Livin as a useful prognostic factor for rectal cancer patients.

Keywords: Rectal cancer, Livin, Radiotherapy

\section{Background}

Colorectal cancer (CRC) is one of the leading causes of cancer death in Western countries [1,2]. Surgery remains the curative modality for the CRC, and preoperative radiotherapy (RT) has shown a survival advantage compared with surgery alone. However, the value of preoperative RT still remains controversial [3-5]. There is an urgent need to search for predictive indicators to identify patients who can be benefited from preoperative radiotherapy.

Many molecules that participate the biological process of proliferation and apoptosis have been proposed as potential indicators for RT. We have previously reported that Survivin from the Inhibitor of Apoptosis (IAP)

\footnotetext{
* Correspondence: xiao-feng.sun@liu.se

'Division of Oncology, Department of Clinical and Experimental Medicine, Faculty of Health Sciences, Country Council of Östergötland, University of Linköping, Linköping, Sweden

Full list of author information is available at the end of the article
}

family is an independent prognostic factor in rectal cancer patients with or without preoperative radiotherapy [6]. Till now, another IAP family member Livin has been identified [7-9]. It is expressed in variant tumors such as melanoma, leukemia, bladder cancer, breast cancer, cervical cancer, nasopharyngeal cancer and lung cancer [10-13]. Two isoforms (designated $\alpha$ - and $\beta$-) were described due to alternative splicing, which are almost identical except for a $54 \mathrm{bp}$ truncation in exon 6 [14]. Both isoforms block apoptosis induced by TNF- $\alpha$ and anti-CD95 antibody.

However, little is known on the Livin expression in CRC except for preliminary in vitro reports [15]. Neither is it known about the relationship between Livin expression and radiotherapy. In this study, we investigated the relationships of Livin expression to radiotherapy and to clinicopathologic or biologic variables in CRC patients who participated in a clinical trial of preoperative radiotherapy.

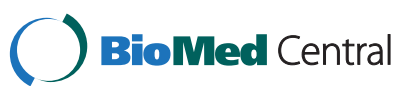




\section{Patients and methods Patients}

The current study got approval from the ethics committee of Linkoping University and was in compliance with the Helsinki Declaration. The present study included 144 rectal cancer patients from the Southeast Swedish Health Care region who participated in the Swedish Rectal Cancer Trial between 1987 and 1990 [3]. Of the 144 patients, 77 underwent tumor resection alone and 67 underwent preoperative RT and tumor resection. None of the patients had received chemotherapy before surgery. Besides the tumor specimens, matched normal mucosa adjacent to the tumor tissue were collected from 71 cases, distant (4-35 cm from the primary tumor) normal mucosa were collected from 110 cases, and metastases in the regional lymph nodes were collected from 47 cases. The mean patient age was 66 years (range, 3685 years). The median follow-up was 85 months. RT was given to 25 Gy in five fractions during a median of 8.5 Days (range, 6-18 days) [3]. Surgery was then performed in a median of 3.4 days (0-11 days) after RT. The mean tumor distance to the anal verge was $7.4 \mathrm{~cm}$ in the surgical group and $8.6 \mathrm{~cm}$ in the surgery plus RT group $(P=$ $0.10)$. Other patient and tumor characteristics were presented in Table 1 . No statistically significant differences were found between the two groups.

\section{Immunohistochemical (IHC) assay}

Representative paraffin-embedded tissue blocks were selected for the tissue microarray. Three morphologically representative regions were chosen in each block and three cyclindrical core core tissue specimens $(0.6 \mathrm{~mm}$ in diameter) were taken from these areas, inserted in another paraffin block. Sections from the second block were cut into $5 \mu \mathrm{m}$ chips using a microtome, mounted on microscopic slides. The tissue microarrays were constructed using a manual arrayer (Beecher Inc., WI).

IHC for Livin expression was done on $5-\mu \mathrm{M}$ tissue microarray sections from paraffin-embedded surgical specimens. The sections were baked in an oven at $60^{\circ} \mathrm{C}$ for over $6 \mathrm{hrs}$ and then deparaffinized with xylene and rehydrated with a series of decreasing concentrations of ethanol. To demask antigen epitopes, the sections were soaked in DIVA solution (Biocare Medical, CA) in a high pressure cooker at $125^{\circ} \mathrm{C}$ for $30 \mathrm{sec}$ after which the sections were cooled to $90^{\circ} \mathrm{C}$ for $10 \mathrm{sec}$ and then kept in room temperature for $30 \mathrm{~min}$ followed by washing in phosphate buffered solution (PBS, $\mathrm{pH}$ 7.4). To inhibit endogenous peroxidase activity, the sections were incubated with $3 \%$ H2O2-methanol for $20 \mathrm{~min}$. After blocking with power block solution (Spring Bioscience, CA) for $10 \mathrm{~min}$, the sections were incubated with goat anti-Livin antibody $(\mathrm{RnD}$, $\mathrm{MN}$ ) at a concentration of $2.5 \mu \mathrm{g} / \mathrm{ml}$ at $4^{\circ} \mathrm{C}$ overnight. EnVision anti-goat Polymeric conjugate (Dako, Carpinteria,
Table 1 Characteristics of patients and tumors

\begin{tabular}{|c|c|c|}
\hline Characteristics & $\begin{array}{l}\text { Non radiotherapy } n \\
(\%)\end{array}$ & $\begin{array}{l}\text { Radiotherapy n } \\
\text { (\%) }\end{array}$ \\
\hline \multicolumn{3}{|l|}{ Gender } \\
\hline Male & $44(57)$ & $42(63)$ \\
\hline Female & $33(43)$ & $25(37)$ \\
\hline \multicolumn{3}{|l|}{ Age (years) } \\
\hline$\leq 70$ & $45(58)$ & $45(67)$ \\
\hline$>70$ & $32(42)$ & $22(33)$ \\
\hline \multicolumn{3}{|l|}{ TNM stage } \\
\hline 1 & $19(25)$ & $20(30)$ \\
\hline$\|$ & $19(25)$ & $22(33)$ \\
\hline III & $35(45)$ & $19(28)$ \\
\hline IV & $4(5)$ & $6(9)$ \\
\hline \multicolumn{3}{|l|}{ Differentiation } \\
\hline Good & $60(78)$ & $49(73)$ \\
\hline Poor & $17(22)$ & $18(27)$ \\
\hline \multicolumn{3}{|c|}{ Number of malignancies } \\
\hline Single & $65(84)$ & $55(82)$ \\
\hline Multiple & $10(13)$ & $12(18)$ \\
\hline Unknown & $2(3)$ & 0 \\
\hline \multicolumn{3}{|l|}{ Surgical type } \\
\hline Rectal amputation & $42(55)$ & $24(36)$ \\
\hline Anterior resection & $35(45)$ & $43(64)$ \\
\hline \multicolumn{3}{|l|}{ Resection margin } \\
\hline Tumor free & $73(95)$ & $63(94)$ \\
\hline Tumor & $4(5)$ & $4(6)$ \\
\hline \multicolumn{3}{|l|}{$\begin{array}{l}\text { Distance to anal verge } \\
(\mathrm{cm})\end{array}$} \\
\hline Mean & 7.4 & 8.6 \\
\hline
\end{tabular}

CA) was subsequently applied for $30 \mathrm{~min}$. The slides were washed in PBS and the peroxidase reaction was performed using 3,3'-diaminobenzidin (Sigma Chemical, St. Louis, $\mathrm{MO}$ ) and 3\% $\mathrm{H} 2 \mathrm{O} 2$. Finally, hematoxylin was used for counterstaining. Sections known to show positive staining for Livin were included for each turn, receiving either the primary antibody or control isotype Ig, as positive or negative controls, whereas there was no staining in the negative controls.

\section{Measurement of the Livin expression by IHC}

The IHC results of the Livin in tissue specimens were the mean of scores by two independent authors (Z.-Y. D., and H. Z., who is a pathologist) in a blinded fashion without knowledge of the clinicopathological or biological information. Each investigator estimated the proportion of cells stained and the intensity of staining in the whole section. The intensity in epithelial cells or tumor cells was scored as 0 (negative staining), 1 (weak staining exhibited as light 
yellow), 2 (moderate staining exhibited as yellow brown), and 3 (strong staining exhibited as brown). If there was a discrepancy in individual scores, then both investigators re-evaluated the slides together to reach a consensus before combining the individual scores. To avoid an artificial effect, the cells on the margins of the sections and in areas with poor morphology were not counted.

\section{Evaluation of proliferation, P53, mammary tumor $8 \mathrm{kDa}$ (MAT8), ataxia telangiectasia mutated (ATM), apoptosis, and necrosis}

Proliferation in the cancer cells was measured using IHC for Ki-67 as an indicator $(n=115)$. Low and high proliferation were defined in sections where $<32 \%$ or $\geq 32 \%$ of cancer cells expressed Ki-67 [16]. The data for P53 $(n=139)$, MAT8 $(n=124)$ and ATM $(n=66)$ of primary rectal cancers determined by IHC were taken from previous studies performed with the same cases used in the present study at out laboratory [17-19]. Apoptosis was detected by the terminal deoxynucleotidy transferase-mediated dUTP-biotin nick end labeling (TUNEL) assay [20].

\section{Cell culture}

Human colon cancer cell lines RKO and SW620 were purchased from the American Type Culture Collection. Cells were maintained in Minimal Essential Medium (SigmaAldrich) supplemented with 10\% FBS (GIBCO, Invitrogen, Carlsbad, USA), $1.5 \mathrm{mM}$ L-glutamine (GIBCO) and $1 \mathrm{X}$ PEST (GIBCO) at $37^{\circ} \mathrm{C}$ in a $5 \% \mathrm{CO} 2$ incubator. Mycoplasma contamination was excluded from the cells by using a commercially available PCR kit (PromoKine, Heidelberg, Germany). The endogenous Livin was knockdown with ON-TARGETplus ${ }^{\mathrm{R}}$ SMARTpool siRNA against Livin (L-004391-00-5551, Thermo Fisher) by using DharmaFect 2 transfection reagent (Dharmacon) according to the manufacturer' instructions. The transfection mixture consisted of antibiotic-free culture medium and 100 nM siRNA. The Dharmacon Non-Targeting scramble siRNA was used as a negative control.

\section{Cell proliferation assay}

The effect of radiotherapy on the proliferation of colon cancer cells was quantified by WST-1 assay (Roche) according to the manufacture's instructions. Briefly, cells were seeded in 96-well tissue culture plate, in $100 \mu \mathrm{l} \mathrm{cul-}$ ture medium. $10 \mu \mathrm{l}$ of WST-1 assay solution was added to each well and the cells were further incubated at $37^{\circ} \mathrm{C}$ for 2-3 hrs. The absorbance was measured at a wavelength of $450 \mathrm{~nm}$ on a VersaMax microplate reader (Molecular Devices, Sunnyvale, CA). Untreated cells served as the indicator of $100 \%$ cell viability.

\section{Statistical analysis}

All the statistical analyses were performed by using the SPSS software 19.0 (IBM software). The McNemar and Chi-Square methods were used to test the statistical significance of the differences in the Livin expression between different tissue specimens and the association of Livin with the clinicopathological features, Ki-67, P53, MAT8 and ATM. Cox's proportional hazard model used to estimate the relationship between Livin expression and survival, including both univariate and multivariate analyses. Survival curves were computed according to the Kaplan-Meier method. Tests were two-sided, and $P<0.05$ was considered statistically significant.

\section{Results}

Livin expression in normal mucosa, primary tumor and lymph node metastasis

By immunostaining, Livin expression was predominantly detected in the cytoplasm of epithelial cells of normal mucosa, and tumor cells of primary cancers and lymph node metastases, with little staining in the nuclei (Figure 1A and Additional file 1). For further analysis of the study, only the staining of the cytoplasmic Livin was measured and presented. Of the 144 primary tumors examined, Livin expression was negative in 13 cases (9\%), weak in 32 cases (22\%), moderate in 72 cases (50\%), and strong in 27 cases (19\%). The frequency of high expression (moderate or strong staining) of Livin was significantly increased from distant normal mucosa $(17 \%, 19 / 110 ; P=0.028)$ or adjacent normal mucosa $(17 \%, 12 / 71 ; P=0.051)$ to primary tumors $(69 \%, 99 / 144)$, while the expression was not different from primary tumors to lymph node metastases $(40 \%, 19 / 47$; $P=0.357)$. There was no significant difference between distant and adjacent normal mucosa $(P=0.367$, Figure $1 B)$.

\section{Effect of preoperative RT on Livin expression in the normal mucosa, primary cancer and lymph node metastasis}

Compared with the cases without preoperative RT, the frequency of Livin-positive expression in primary cancers with preoperative RT was decreased from $97 \%$ to $83 \%(P=0.004)$, while in the distant normal mucosa, the frequency of Livin-positive expression was increased (71\% VS $89 \%, P=0.021$ ). However, Livin-positive cases in adjacent normal mucosa were not significantly influenced by RT ( $75 \%$ VS $76 \%, P=0.931)$. The frequency of Livin-positive cases in the lymph node metastases was unchanged in cases receiving preoperative RT (86\% VS $90 \%, P=0.986)$.

\section{Livin expression in relation to clinicopathological and biological factors}

In primary cancers, the expression of Livin was associated with lower frequency of stage I and higher frequency of 
stage II, III or IV cases $(P=0.044)$, and related to poor differentiation of cancers $(P=0.033$, Figure 2A). Patients with Livin-positive or negative tumors had similar local $(P=$ $0.647)$ and distant $(P=0.280)$ recurrence. The expression of Livin was not related to gender, or age $(P>0.05) .15 .4 \%$ $(2 / 13)$ and $39.7 \%(52 / 131)$ patients with Livin-negative or positive tumors died at 180 months after surgery, and the difference tended to be statistically significant $(P=0.091$, Figure 2B). In multivariate analyses, the difference achieved statistical significance, independent of TNM stage, local and distant recurrence, grade of differentiation, gender, and age $(P=0.048$, Table 2$)$.

In a subgroup analysis of the patients with preoperative RT, a statistically significant difference was observed between patients with Livin-positive or negative tumors $(P=0.047)$. We did not find any relationship of Livin expression to TNM stage, grade of differentiation, gender, or age in this subgroup $(P>0.05)$. Due to a few cases with Livin-negative tumors in the subgroup of the patients without preoperative RT, we did not perform statistical analysis in the subgroup.

In the entire group, the frequency of expression of Livin was related to the expression of Ki-67 $(P=0.027)$, p53 $(P=0.012)$, MAT8 $(P=0.020)$ and inversely related to $\operatorname{ATM}(P=0.007)$.

In the patients without preoperative RT, high expression of Livin was still related to MAT8 $(P=0.032)$ and p53 $(P=0.048)$, and inversely related to ATM $(P=0.037$,
Figure 3$)$. In the patients with preoperative RT, no trend was observed toward any of the relationship $(P>0.05)$.

In the current study, the median overall survival was similar between patients with (129 months) or without (114 months) preoperative RT $(P=0.252)$.

\section{Knock-down of Livin inhibited the proliferation of colon cancer cells after irradiation}

The endogenous Livin in SW620 and RKO colon cancer cells was knocked-down by siRNA. The non-targeting scramble siRNA was used as controls. The proliferation of cancer cells after irradiation was monitored continuously by WST-1 method. The colon cancer cells with Livin knock-down exhibited significant decrease in proliferation at each time point, compared scramble siRNA treated controls $(P<0.05$, Figure 4$)$.

\section{Discussion}

This is the first study of Livin expression in rectal cancer patients who participated in a trial of preoperative RT. Livin expression was described in colon cancer cell lines at the protein or mRNA level [15,21-23], however few reported the expression of Livin in rectal cancer tissues. Yagihashi et al reported the detection of anti-Livin autoantibody in gastrointestinal patients, but this study failed to confirm the Livin expression in tumor tissues either [24]. In the present study, we found the extensive expression (91\%) of Livin in CRC tissue specimens. We
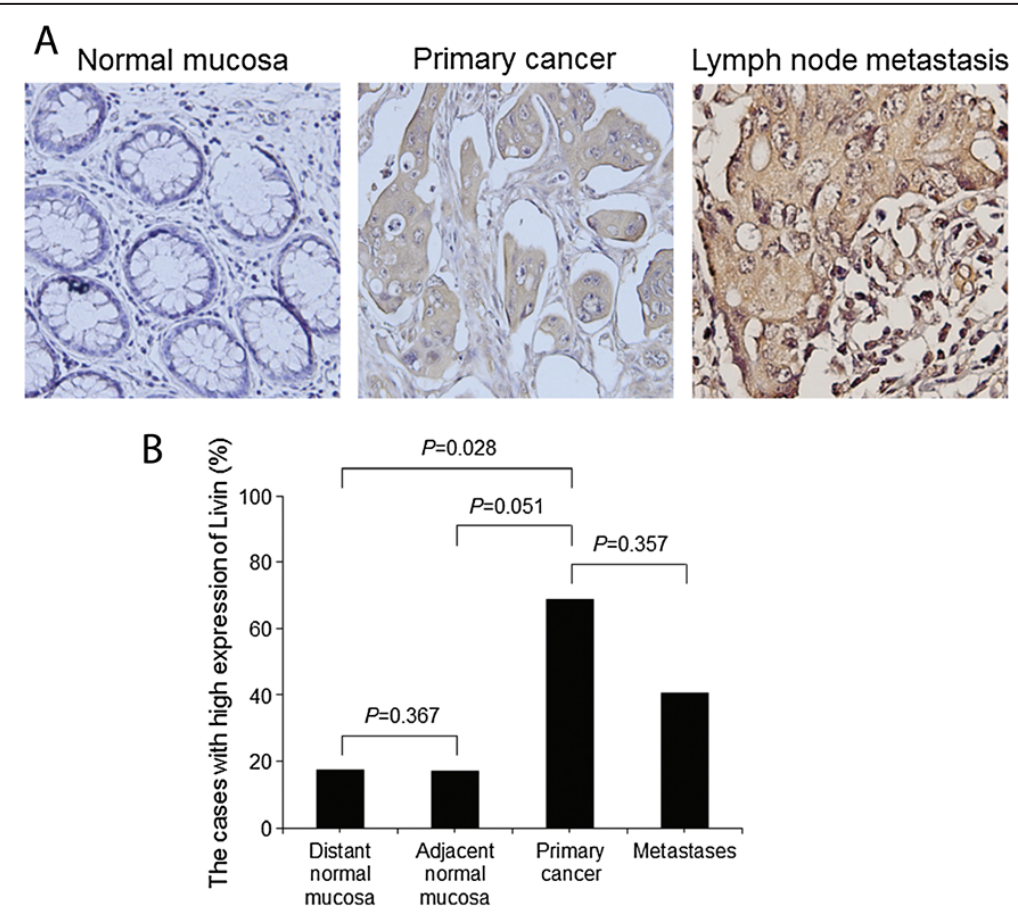

Figure 1 Livin expression in tumors and mucosa. Livin expression in normal mucosa, primary cancer, and lymph node metastases (A). The percentage of Livin high expresssion differes significantly between primary cancer and adjacent or distant normal mucosa (B). 


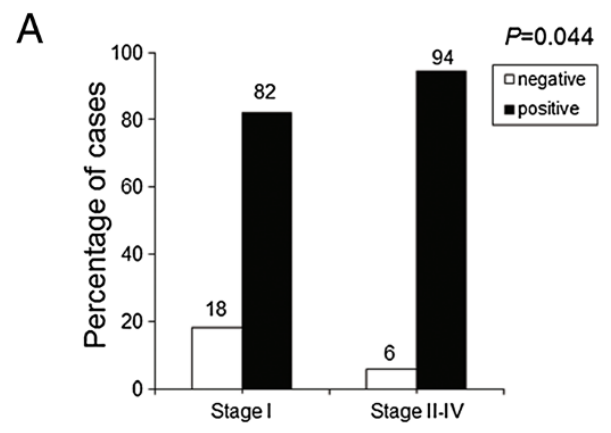

TNM stage
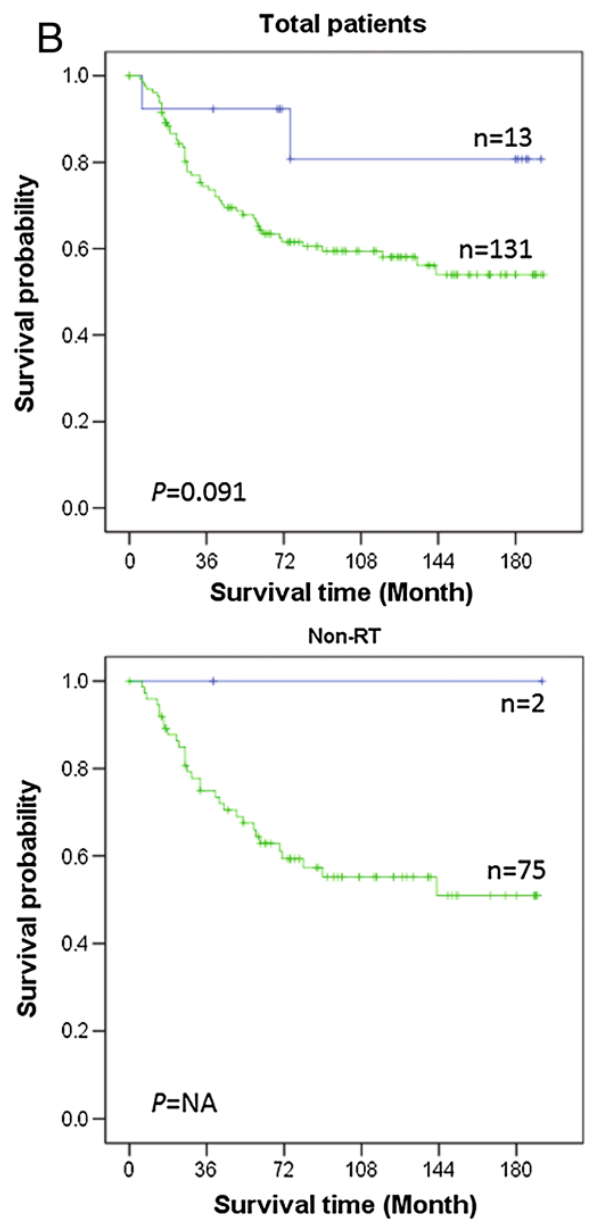
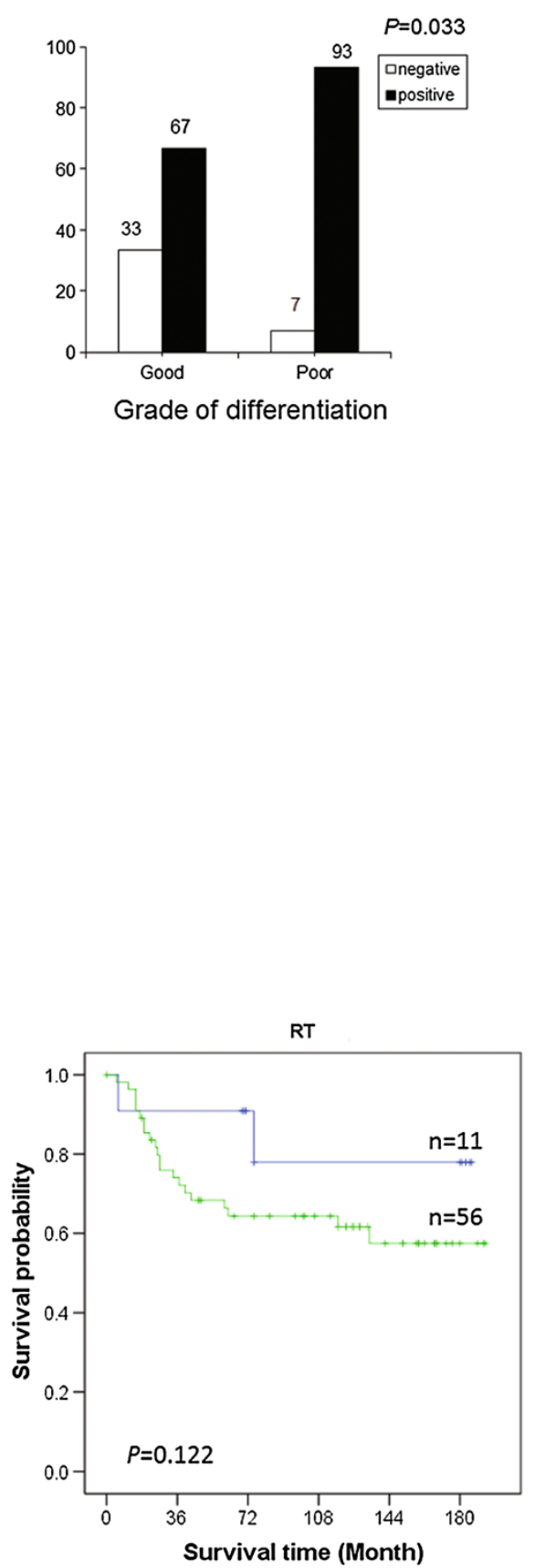

Figure 2 Livin expression in relation to clinicopathological factors. Significant difference in Livin expression between early to advanced stage or good to poor differentiation (A). Livin expression in relation to survival in entire group and subgroup with or without radiotherapy (B).

also detected Livin expression in 7 from 7 colon cancer cell lines [25]. The prevalent expression of Livin in CRC tissues and cells suggested it plays a prominent role for the progression of CRC.

Controversies remained on the prognostic value of Livin in different tumor types. Livin over-expression together with C-myc amplification in patients with neuroblastoma predicated a poor prognosis [26]. In patients with bladder cancer, increased Livin expression in tumors was associated with shorter duration of relapse-free survival [11]. Livin expression was also parallel with a decreased overall survival in osteosarcoma patients [27]. Although most studies supported the negative impact of Livin on survival, mild influence or even favored prognosis was also reported. One paper implicated the Livin expression was a favorable prognostic factor in childhood acute lymphoblastic leukemia [12]. However, the authors did not provide explanations for the counter-instinctive results. In summary, it would be 
Table 2 multivariate analysis of Livin in tumors in relation to survival

\begin{tabular}{|c|c|c|c|}
\hline Factor & Patients (n) & Cancer death rate ratio ( $95 \%$ confidence interval) & $p$ value \\
\hline Livin expression & & & 0.048 \\
\hline Negative & 13 & 1.0 & \\
\hline Positive & 131 & $5.09(1.01-25.64)$ & \\
\hline Gender & & & 0.917 \\
\hline Male & 86 & 1.0 & \\
\hline Female & 58 & $0.97(0.52-1.79)$ & \\
\hline Age (years) & & & 0.779 \\
\hline$\leq 70$ & 90 & 1.0 & \\
\hline$>70$ & 54 & $1.08(0.62-1.90)$ & \\
\hline Tumor stage & & & $<0.001$ \\
\hline$I+\|+\| I$ & 134 & 1.0 & \\
\hline IV & 10 & $5.40(2.13-13.69)$ & \\
\hline Differentiation & & & 0.881 \\
\hline Poor & 138 & 1.0 & \\
\hline Good & 6 & $1.10(0.31-3.99)$ & \\
\hline Local recurrence & & & $<0.001$ \\
\hline No & 121 & 1.0 & \\
\hline Yes & 23 & $3.31(1.78-6.17)$ & \\
\hline Distant recurrence & & & $<0.001$ \\
\hline No & 85 & 1.0 & \\
\hline Yes & 59 & $12.48(5.60-27.75)$ & \\
\hline
\end{tabular}

reasonable to suggest the prognostic significance of Livin is tissue and tumor specific. In the current study, we found that Livin expression was an independent prognostic factor for CRC patients after adjustment for TNM stage, local and distant recurrence, grade of differentiation, gender, and age. Our results provide new evidence in support of the important roles played by Livin in variant cancers.

In the present study, we individually examined the relationship between Livin expression and survival in the patients with or without preoperative RT. Our results showed Livin expression in both the entire group and the subgroup of patients receiving preoperative RT was statistically related to poor prognosis. In the subgroup of patients without preoperative RT, the expression of Livin seemed to be related to the shorter overall survival. The survival rate in patients with Livin-negative cancers was $100 \%(2 / 2)$ at 200 months after surgery. These evidence supported the notion that Livin was related to survival in CRC patients regardless of receiving preoperative RT or surgery alone.

Few studies reported the differential expression of Livin between primary cancers and adjacent normal mucosa. In
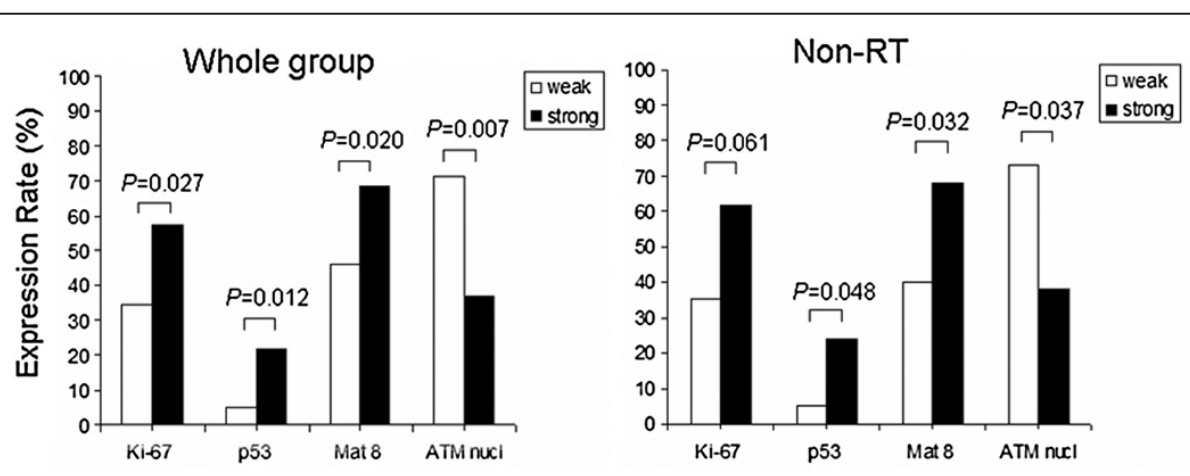

Figure 3 Livin expression in relation to other factors. The expression of Livin was related to the expression of Ki-67, p53, MAT8 and inversely related to ATM in both the entire group and non-RT subgroup patients. 
SW620

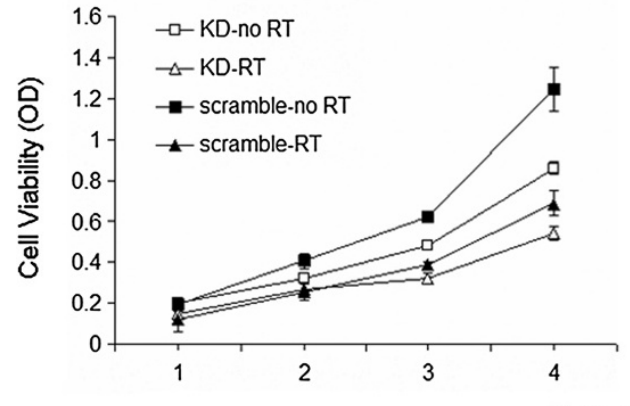

RKO

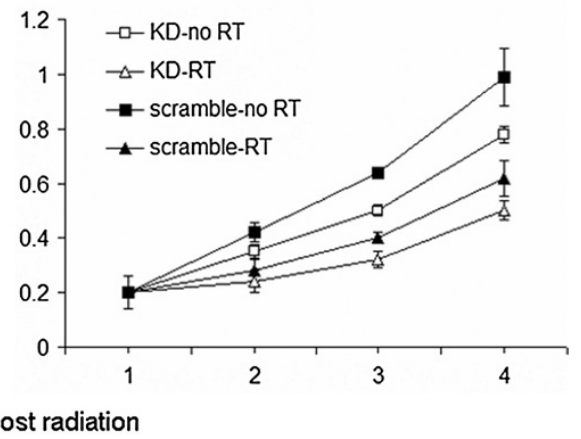

Figure 4 Knock-down of Livin makes cells more vulnerable to RT.

the current study, we found Livin was over-expressed in $69 \%$ of primay cancers and $40 \%$ of lymph node metastases, but only $17 \%$ of adjacent normal mucosa and $17 \%$ of distant normal mucosa. The frequency of high expression of Livin was much higher in malignant tissues than in normal mucosa. Studies performed in cancer cells lines implicated the expression of Livin was under the regulation of Catenin/TCF or mTOR pathways [28,29] which were considered hallmark signaling changes in cancers [30]. These studies together with our results indicated the Livin deregulation may contribute to the malignant manifestation in cancers and may serve as a potential therapeutic targets [31].

We analyzed the influence of preoperative RT on the Livin expression, and observed a decrease of Livin expression in primary cancers in patients receiving preoperative RT. Cancers have deregulated apoptotic pathway to protect them against harmful stimuli including radiation [30]. Anti-cancer treatment would overcome these molecular hurdles to be effective [32]. In this way we believe Livin was down-regulated by the preoperative RT in primary cancers. The adjacent normal mucosa was suggested a place of intermediate biologic change and had a similar tendency with the primary cancers. However, Livin in the distant mucosa might be up-regulated to protect the cells from apoptosis by RT.

The underlying mechanism of Livin expression in association with poor prognosis was probably attributed to the negative regulation of apoptosis in response to RT. Livin was proposed to block apoptosis by inhibiting the activity of caspases $[7,8]$ or involved in the TAK1/JNK1 pathway [33]. In the present study, we did not prove the relationship between Livin expression and apoptosis in the rectal cancer tissues. Similarly, our previous study on Survivin did not prove the relationship to the apoptosis rate either [6]. One of the reasons may be due to the "surgery-related apoptosis" which might influence our results concerning apoptosis in relation to Livin expression. We further analyzed the relationship of Livin with $\mathrm{Ki}-67, \mathrm{P} 53, \mathrm{MAT}$, and ATM. Ki-67 is a proven indicator of cell proliferation [16]. P53 detected in IHC is a mutated protein with oncogene properties [17]. MAT8 also named FXYD-3, is a chloride channel or chloride channel regulator and acts as a prognostic factor for cancers [18]. Livin expression was inversely related to ATM which is a serine/threonine protein kinase in the DNA damage repair pathway [34]. Our findings suggested Livin might be involved in variant pathways in the cell malignant phenotypes.

It should be noted that debate remained as to whether apoptosis contributed to radiotherapy [35]. It was proposed that apoptosis contributed to the short-term cytocidal effects of radiotherapy, but not to the long-term clone formation. In our study, we found the expression of Livin was related to the prognosis in patients. We wouldn't be able to find the association between Livin expression and apoptosis in this cohort of patients. These results were in good agreement to the proposal mentioned above. Therefore, the mechanistic explanation for the current observations couldn't be simply attributed to apoptosis. Livin might be involved in other phenotypes too. In support of this, a paper described its regulation in cell cycle was published [36].

Our in vitro study showed decreased proliferation of SW620 and RKO colon cancer cells after radiation when the endogenous Livin was knocked down by RNAi. Consistent with our findings, recent studies provided evidence to support the role of Livin for treatment resistance. Crnkovic-Mertens et al reported silencing Livin expression strongly increased the apoptotic rate in response to different stimuli $[37,38]$. Besides, Wang et al showed silencing Livin inhibited the proliferation of tumor cells [22]. The inhibition of proliferation was probably related to cell cycle regulation [36]. Our previous results also showed knock-down of Livin rendered the colon cancer cells more sensitive to chemotherapy agent cisplatin [25]. The 
inhibiting role of Livin in colon cancer cells was consistent with the immunostaining results, where Livin was found to be related to poor prognosis.

Of notice, the patients in our study were from a previous randomized trial [3]. Although they were well-balanced between groups (Table 1), the sample size was restricted to the available banked tissue samples. The limited number of patients prevented any conclusive results. Additionally, although our multivariate analysis might be helpful, the problem of the heterogeneity in patients (stage I-IV) could not be completely solved. All these limitations indicated the results should be interpreted cautiously.

In summary, our study showed increased Livin expression in primary rectal cancers was related to the more advanced stage of cancer. Livin expression was independently related to survival in rectal cancer patients who participated in a trial of preoperative RT, and it was associated with survival in subgroup of patients receiving preoperative RT too. Livin expression tended to be down regulated by RT. Taken together, our data implicated Livin was a useful prognostic factor for rectal cancer patients and possibly served as a potential therapeutic target.

\section{Consent}

Written informed consent was obtained from the patient for the publication of this report and any accompanying images.

\section{Additional file}

Additional file 1: IHC staining of Livin. Typical presentation of weak (A) and strong (B) staining signals of Livin.

\section{Abbreviations}

RT: Radiotherapy; CRC: Colorectal cancer; IAP: Inhibitor of apoptosis.

\section{Competing interests}

The authors declare that they have no competing interests.

\section{Authors' contributions}

DZ collected and analyzed the data and prepared the manuscript; ZH participated in the analyzing the $\mathrm{HC}$ data; $\mathrm{AG}$ and $\mathrm{OB}$ provided the critical revision of the manuscript and the administrative support; SX provided the conception of the study and the final approval of the final version. All authors read and approved the final manuscript.

\section{Acknowledgements}

This study was supported by grants from National Major Project of China (No.2011ZX09302-001-01), National Natural Science Fund of China (81272684), Swedish Cancer Foundation, Swedish Research Council and the Health Research Council in the South-East of Sweden.

\section{Author details}

'Division of Oncology, Department of Clinical and Experimental Medicine, Faculty of Health Sciences, Country Council of Östergötland, University of Linköping, Linköping, Sweden. ${ }^{2}$ Department of Thoracic Oncology, Cancer Center, and the State Key Laboratory of Biotherapy, West China Hospital, West China Medical School, Sichuan University, Chengdu, China. ${ }^{3}$ School of Medicine, Örebro University, SE 70182 Örebro, Sweden. ${ }^{4}$ Department of Oncology, Karolinska University Hospital, Stockholm, Sweden.
Received: 7 July 2013 Accepted: 17 November 2013

Published: 2 December 2013

\section{References}

1. Jemal A, Siegel R, Xu J, Ward E: Cancer statistics, 2010. CA Canc J Clin 2010, 60:277-300

2. Meza R, Jeon J, Renehan AG, Luebeck EG: Colorectal cancer incidence trends in the United States and United kingdom: evidence of right- to left-sided biological gradients with implications for screening. Canc Res 2010, 70:5419-5429.

3. Trial SRC: Improved survival with preoperative radiotherapy in resectable rectal cancer. N Engl J Med 1997, 336:980-987.

4. Camma C, Giunta M, Fiorica F, Pagliaro L, Craxi A, Cottone M: Preoperative radiotherapy for resectable rectal cancer: A meta-analysis. JAMA 2000, 284:1008-1015.

5. Van Den Brink M, Van Den Hout WB, Stiggelbout AM, et al: Cost-utility analysis of preoperative radiotherapy in patients with rectal cancer undergoing total mesorectal excision: a study of the Dutch Colorectal Cancer Group. J Clin Oncol 2004, 22:244-253.

6. Knutsen A, Adell G, Sun XF: Survivin expression is an independent prognostic factor in rectal cancer patients with and without preoperative radiotherapy. Int J Radiat Oncol Biol Phys 2004, 60:149-155.

7. Lin JH, Deng G, Huang Q, Morser J: KIAP, a novel member of the inhibitor of apoptosis protein family. Biochem Biophys Res Commun 2000, 279:820-831.

8. Vucic D, Stennicke HR, Pisabarro MT, Salvesen GS, Dixit VM: ML-IAP, a novel inhibitor of apoptosis that is preferentially expressed in human melanomas. Curr Biol 2000, 10:1359-1366.

9. Kasof GM, Gomes BC: Livin, a novel inhibitor of apoptosis protein family member. J Biol Chem 2001, 276:3238-3246.

10. Tanabe H, Yagihashi A, Tsuji N, Shijubo Y, Abe S, Watanabe N: Expression of survivin mRNA and livin mRNA in non-small-cell lung cancer. Lung Canc 2004, 46:299-304.

11. Gazzaniga P, Gradilone A, Giuliani L, et al: Expression and prognostic significance of LIVIN, SURVIVIN and other apoptosis-related genes in the progression of superficial bladder cancer. Ann Oncol 2003, 14:85-90.

12. Choi J, Hwang YK, Sung KW, et al: Expression of Livin, an antiapoptotic protein, is an independent favorable prognostic factor in childhood acute lymphoblastic leukemia. Blood 2007, 109:471-477.

13. Xiang $Y$, Yao H, Wang $\mathrm{S}$, et al: Prognostic value of Survivin and Livin in nasopharyngeal carcinoma. Laryngoscope 2006, 116:126-130.

14. Ashhab Y, Alian A, Polliack A, Panet A, Ben Yehuda D: Two splicing variants of a new inhibitor of apoptosis gene with different biological properties and tissue distribution pattern. FEBS Lett 2001, 495:56-60.

15. Takeuchi H, Kim J, Fujimoto A, et al: X-Linked inhibitor of apoptosis protein expression level in colorectal cancer is regulated by hepatocyte growth factor/C-met pathway via Akt signaling. Clin Canc Res 2005, 11:7621-7628.

16. Adell G, Zhang H, Jansson A, Sun XF, Stal O, Nordenskjold B: Decreased tumor cell proliferation as an indicator of the effect of preoperative radiotherapy of rectal cancer. Int J Radiat Oncol Biol Phys 2001, 50:659-663.

17. Adell G, Sun XF, Stal O, Klintenberg C, Sjodahl R, Nordenskjold B: p53 status: an indicator for the effect of preoperative radiotherapy of rectal cancer. Radiother Oncol 1999, 51:169-174.

18. Loftas $P$, Onnesjo S, Widegren E, et al: Expression of FXYD-3 is an independent prognostic factor in rectal cancer patients with preoperative radiotherapy. Int J Radiat Oncol Biol Phys 2009, 75:137-142.

19. Arlehag L, Adell G, Knutsen A, Thorstenson S, Sun XF: ATM expression in rectal cancers with or without preoperative radiotherapy. Oncol Rep 2005, 14:313-317.

20. Adell GC, Zhang H, Evertsson S, Sun XF, Stal OH, Nordenskjold BA: Apoptosis in rectal carcinoma: prognosis and recurrence after preoperative radiotherapy. Cancer 2001, 91:1870-1875.

21. Yang L, Cao Z, Yan H, Wood WC: Coexistence of high levels of apoptotic signaling and inhibitor of apoptosis proteins in human tumor cells: implication for cancer specific therapy. Canc Res 2003, 63:6815-6824.

22. Wang $R$, Lin $F$, Wang $X$, et al: Silencing Livin gene expression to inhibit proliferation and enhance chemosensitivity in tumor cells. Canc Gene Ther 2008, 15:402-412.

23. Slagsvold JE, Pettersen CH, Storvold GL, Follestad T, Krokan HE, Schonberg SA: DHA alters expression of target proteins of cancer therapy in 
chemotherapy resistant SW620 colon cancer cells. Nutr Canc 2010, 62:611-621.

24. Yagihashi A, Ohmura $T$, Asanuma $K$, et al: Detection of autoantibodies to survivin and livin in sera from patients with breast cancer. Clin Chim Acta 2005, 362:125-130.

25. Ding ZY, Liu GH, Birgit O, Sun XF: Upregulation of the antiapoptotic factor Livin contributes to cisplatin resistance in colon cancer cells. Tumor Biol 2013, 34:683-693.

26. Kim DK, Alvarado CS, Abramowsky CR, et al: Expression of inhibitor-ofapoptosis protein (IAP) livin by neuroblastoma cells: correlation with prognostic factors and outcome. Pediatr Dev Pathol 2005, 8:621-629.

27. Nedelcu T, Kubista B, Koller A, et al: Livin and Bcl-2 expression in highgrade osteosarcoma. J Canc Res Clin Oncol 2008, 134:237-244.

28. Yuan D, Liu L, Gu D: Transcriptional regulation of livin by beta-catenin/ TCF signaling in human lung cancer cell lines. Mol Cell Biochem 2007, 306:171-178.

29. Yan B, Kong M, Chen S, Chen YH: VEGF stimulation enhances Livin protein synthesis through mTOR signaling. J Cell Biochem 2010, 111:1114-1124.

30. Hanahan D, Weinberg RA: Hallmarks of cancer: the next generation. Cell 2011, 144:646-674

31. Chang H, Schimmer AD: Livin/melanoma inhibitor of apoptosis protein as a potential therapeutic target for the treatment of malignancy. Mol CancTher 2007, 6:24-30.

32. Luo J, Solimini NL, Elledge SJ: Principles of cancer therapy: oncogene and non-oncogene addiction. Cell 2009, 136:823-837.

33. Sanna MG, da Silva CJ, Ducrey O, et al: IAP suppression of apoptosis involves distinct mechanisms: the TAK1/JNK1 signaling cascade and caspase inhibition. Mol Cell Biol 2002, 22:1754-1766.

34. Lee JH, Paull TT: Activation and regulation of ATM kinase activity in response to DNA double-strand breaks. Oncogene 2007, 26:7741-7748.

35. Brown JM, Attardi LD: The role of apoptosis in cancer development and treatment response. Nat Rev Canc 2005, 5:231-237.

36. Ye L, Song $X$, Li S, et al: Livin-alpha promotes cell proliferation by regulating G1-S cell cycle transition in prostate cancer. Prostate 2011, 71:42-51.

37. Crnkovic-Mertens I, Hoppe-Seyler F, Butz K: Induction of apoptosis in tumor cells by siRNA-mediated silencing of the livin/ML-IAP/KIAP gene. Oncogene 2003, 22:8330-8336.

38. Crnkovic-Mertens I, Semzow J, Hoppe-Seyler F, Butz K: Isoform-specific silencing of the Livin gene by RNA interference defines Livin beta as key mediator of apoptosis inhibition in HeLa cells. J Mol Med (Berl) 2006, 84:232-240.

doi:10.1186/1748-717X-8-281

Cite this article as: Ding et al: Livin expression is an independent factor in rectal cancer patients with or without preoperative radiotherapy.

Radiation Oncology 2013 8:281.

\section{Submit your next manuscript to BioMed Central and take full advantage of:}

- Convenient online submission

- Thorough peer review

- No space constraints or color figure charges

- Immediate publication on acceptance

- Inclusion in PubMed, CAS, Scopus and Google Scholar

- Research which is freely available for redistribution 